\title{
Evaluation of the effects of the powder of Capsicum frutescens on glycemia in growing rabbits
}

\author{
Tossou Jacques Dougnon ${ }^{1}$ and Messanvi Gbeassor ${ }^{2}$
}

1. Laboratory of Research in Applied Biology, Polytechnic School of Abomey-Calavi, University of Abomey-Calavi, 01 BP 2009 Abomey-Calavi, Benin; 2. Faculty of Sciences, University of Lomé (Togo), BP 1515, Lomé, Togo. Corresponding author: Tossou Jacques Dougnon, e-mail: dougnonj@yahoo.fr, MG: mgbeassor@yahoo.fr

Received: 28-11-2015, Revised: 16-01-2016, Accepted: 25-01-2016, Published online: 16-03-2016

doi: 10.14202/vetworld.2016.281-286 How to cite this article: Dougnon TJ, Gbeassor M (2016) Evaluation of the effects of the powder of Capsicum frutescens on glycemia in growing rabbits, Veterinary World, 9(3): 281-286.

\begin{abstract}
Aim: The present study aims to evaluate zootechnic parameters and blood sugar in rabbits submitted to diets containing different levels of pepper (Capsicum frutescens).

Materials and Methods: To this end, 30 rabbits weighing on average $1252 \pm 35 \mathrm{~g}$ at the beginning of the experiment were subjected to five rations with three repetitions for 56 days: The food R0 (or control) which is floury provender contains $0 \%$ of $C$. frutescens; R5, R10, R15, and R20 provender containing, respectively, $0.5 \%, 1 \%, 1.5 \%$, and $2 \%$ of $C$. frutescens fruits' powder. Rabbits consumed on average from 75.47 to $80.97 \mathrm{~g}$ dry matter.

Results: Digestibility ranged from $52.39 \%$ to $61.01 \%$. The average daily gain and feed consumption index were similar for all diets. Blood glucose was amended by the various servings is $0.98 \mathrm{~g} / \mathrm{L}$ and $0.88 \mathrm{~g} / \mathrm{L}$, respectively, for doses.

Conclusion: It appears from this study that rabbits consumed well diets containing $C$. frutescens. However, $C$. frutescens' effect on the growth performances of rabbits is not noticeable. Furthers experiments will be useful to evaluate $C$. frutescens' mechanism of action on blood sugar.
\end{abstract}

Keywords: blood sugar, Capsicum frutescens, consumption index, rabbit.

\section{Introduction}

Food self-sufficiency is one of the key priorities of developing countries in general and in Benin in particular. In fact, meat consumption (13 kg/person/year) in Sub-Saharan countries is below the average recommended by FAO (21 kg/person/year) [1]. Despite this, in the mind of consumers, food should no longer only cover nutritional needs but must contribute to the maintenance of human health [2]. However, it is noticed that one of the main causes of human diseases is malnutrition. Some diseases such as diabetes are major threats $[3,4]$. In Benin, its prevalence is 10 per 10,000 with $1.6 \%$ of deaths and lethality of $12.5 \%$ [5]. In fact, diabetes comes from a metabolic disorder caused by the body's inability to produce insulin, a hypoglycemic hormone secreted by the pancreatic $\beta$-cells of the islets of Langerhans [6]. Currently, diabetes therapy is based on the use of hypoglycemic agents (sulfonylureas, biguanides, and insulin), on lifestyle changes, exercise, and requires lifelong treatment [7]. But, in Benin, due to the lack of access to health facilities and customary beliefs, most of the patients used exclusively or partially to traditional medicine.

Copyright: Dougnon and Gbeassor. Open Access. This article is distributed under the terms of the Creative Commons Attribution 4.0 International License (http://creativecommons.org/licenses/ by/4.0/), which permits unrestricted use, distribution, and reproduction in any medium, provided you give appropriate credit to the original author(s) and the source, provide a link to the Creative Commons license, and indicate if changes were made. The Creative Commons Public Domain Dedication waiver (http:// creativecommons.org/publicdomain/zero/1.0/) applies to the data made available in this article, unless otherwise stated.
In rabbits, the real diabetes is a very rare condition and is barely described in the scientific literature, with the exception of experimentally induced diabetes. When it occurs during the first phase of the disease, rabbits are able to compensate the lack of insulin production by the pancreas. It seems indeed that insulin plays a less important role in rabbits and herbivores in general than in carnivores and men [8]. But it sit could be that diabetes acts on the evolution of rabbits without the knowledge of the producers. Existing types of therapy cannot be used by farmers because of their excessive cost. So, many plants possess hypoglycemic properties, which after ingestion can help rabbits to regulate his glycemia. Capsicum frutescens is a perennial growing to $1 \mathrm{~m}$ ( 3 feet 3 in) by $0.6 \mathrm{~m}$ ( 2 feet). The fruits contain $0.1-1.5 \%$ capsaicin. This substance stimulates the circulation and alters temperature regulation. The seed contains capsicidins. These are thought to have antibiotic properties. However, these plants are not exploited because their food values are not well known [9].

This study aims to evaluate the effects of the powdered fruit of $C$. frutescens on glycemia in growing rabbits. Before we choose our experience doses of C. frutescens $(0.5 \%, 1 \%$, and $1.5 \%)$, we have made another experience with three diets containing $2.5 \%$, $3 \%$, and $3.5 \%$ of $C$. frutescens. This experience lasted 30 days and was conducted on 20 rabbits per diet. At the end, we noticed that these doses of $C$. frutescens $(2.5 \%, 3 \%$, and $3.5 \%)$ in the diet cause behavior troubles on rabbit's body. This justifies the reason why 
we choose these doses of $C$. frutescens $(0.5 \%, 1 \%$, $1.5 \%$, and $2 \%$ ) to conduct our experience, and also as an author said, $C$. frutescens increased serum insulin concentration in a high-fat diet-fed streptozotocin-induced Type 2 diabetes rats after 4 weeks treatment.

\section{Materials and Methods}

\section{Ethical approval}

We note that all animals used for this research are with permission of the Animal Ethics Committee of University of Abomey-Calavi.

30 weaned rabbits with an average weight of $1252 \pm 35 \mathrm{~g}$ were used for this study.

\section{Powder of $\boldsymbol{C}$. frutescens}

Fruits of $C$. frutescens were obtained on the local market and dried in an oven at $65^{\circ} \mathrm{C}$ for $48 \mathrm{~h}$ to evaporate water completely. They were then reduced to powder in a mill (brand: RetschGmb H 5657 HAAN) at the Faculty of Agricultural Science of the University of Abomey-Calavi. An oven was used to determine the dry matter (DM) of prepared foods.

\section{Experimental design and experimental diets}

The experimental design was a full randomized block design with five treatments (R0, R5, R10, R15, and R20). Each lot of animals was randomly assigned to one of five diets. Foods used are: The food R0 (or control), which is floury provender contains $0 \%$ of C. frutescens; R5, R10, R15, and R20 are floury provender containing, respectively, $0.5 \%, 1 \%, 1.5 \%$, and $2 \%$ of $C$. frutescens fruit powder. Each diet is supplemented by oil palm leaves ad libitum will. The composition of the provender used as control food is presented in Table-1. The data of this study suggest that $2 \%$ dietary $C$. frutescens are insulinotropic rather than hypoglycemic in the experimental methods [10].

\section{Conduct of the fattening}

The experiment lasted 56 days and was conducted on rabbits of average live weight $1252 \pm 35 \mathrm{~g}$. 100-130 g DM of food has been distributed to each

Table-1: Control diet composition.

\begin{tabular}{lc}
\hline Raw materials & \% \\
\hline Maize & 5.0 \\
Oil cake of palm tree & 29.0 \\
Cotton oil cake & 16.0 \\
Soya bean oil cake & 7.0 \\
Corn (wheat) & 20.5 \\
Rice & 15.0 \\
Shell of oyster & 2.5 \\
Salt & 0.5 \\
Sawdust & 4.0 \\
Total & 99.5 \\
Chemical composition & \\
DM (\%) & 88.4 \\
Digestible energy* (MJ/kg of DM) & 10.94 \\
Cellulose (\% of DM) & 19.8 \\
Total nitrogenous matter (\% of DM) & 18.8 \\
\hline
\end{tabular}

*The digestible energy of food was obtained from the sum of the energy provided by each raw material entering its composition. Source: [11]. DM=Dry matter rabbit every day from the beginning to the end of the test. The water was distributed ad libitum. Animals were weighed at the start of the test and every 14 days. The quantities of food offered and refused were recorded every 14 days. Evaluation of growth performances focused on the following parameters.

\section{Average daily gain (ADG)}

ADG was calculated per animal and per period of 14-day following formula:

$\mathrm{ADG}=\left(\mathrm{Wd}_{14}-\mathrm{Wdi}\right) / 14$ with Wdi: Weight at day $\mathrm{i}$, and $\mathrm{Wd}_{14}$ : Weight after 14 days of feeding.

\section{Consumption index (CI)}

The CI is the amount of food consumed by an animal in kilograms to win a kilogram of live weight. CI was calculated for periods of 14-day following the formula below:

$$
\mathrm{CI}=\mathrm{I}_{\mathrm{d} 14} / \mathrm{ADG}_{\mathrm{d} 14}
$$

Where, $\mathrm{I}_{\mathrm{d} 14}$ is the amount of DM $(\mathrm{g})$ consumed in 14 days and $\mathrm{ADG}_{\mathrm{d} 14}$ is the average daily weight gain $(\mathrm{g})$ in 14 days of feeding.

\section{Digestibility study}

The digestibility study was conducted at 42 days of the fattening stage on 15 rabbits with a mean weight of $1615.03 \mathrm{~g}$ and divided into five homogeneous lots. The experimental design is the randomized complete block design with five treatments (R0, R5, R10, R15, and R20) which are the five food rations and three repetitions representing rabbits. Animals were placed in individual digestibility cages of $0.202 \mathrm{~m}^{2}$ area and $0.32 \mathrm{~m}$ height. These individual digestibility cages have drinking trough, a manger, and an alluvial collection system. The amount of food served, rejected, and droppings were weighed daily per animal. These samples were dried in an oven at $65^{\circ} \mathrm{C}$ for $48 \mathrm{~h}$ to determine the DM. The experiment lasted 7 days and at the end, the animals were weighed. The quantities of food distributed daily to each rabbit during this period were $100 \mathrm{~g}$ DM of feed and 20-30 g DM oil palm leaves.

\section{Total DM of food consumed}

The amount of DM intake (DMI) per animal was calculated using the formula:

DMI = DMS-DMR with DMI the quantity of food ingested (in $g$ of DM), DMS the quantity of food served (in $g$ of DM), and DMR the food portion refused (in $g$ of DM).

\section{DM digested food}

Knowing the amount of food ingested we can determine the amount of digested food.

DMD = DMI-D with DMD the quantity of food digested (in $g$ of DM), DMI the quantity of food ingested (in $\mathrm{g}$ of DM), and $\mathrm{D}$ the quantity of droppings (in $\mathrm{g}$ of DM).

The coefficient of apparent digestibility (CAD) in total DM was determined as follows:

$\mathrm{CAD}=100 \times \mathrm{DMD} / \mathrm{DMI}$ with DMD the quantity of food digested (in g of DM) and DMI the quantity of food ingested (in $g$ of DM). 


\section{Evaluation of glycemia in rabbits}

Blood samples were collected in dry tubes from the auricular vein from 30 rabbits at the end of the experiment (after 56 days of feeding). Animals were subjected to $12 \mathrm{~h}$ of fasting before sampling. Samples were taken in the morning early at 7 am 30 min using a gauge needle Venoject. Samples were centrifuged for $5 \mathrm{~min}$ at 3200 tour/min, to obtain serum. Glucose rate was determined by spectrophotometry, respectively, with BIOLABO and ELI-tech kits.

\section{Statistics analysis}

The software Statistix 8.0 served for statistical analysis. An analysis of variance (ANOVA) with two factors in the procedure of generalized linear models was used to examine the effects of different diets (R0, R5, R10, R15, and R20), measuring periods ( $\mathrm{n}=4: 14$; $28 ; 42 ; 56$ days) and their interactions on dietary intake, ADG, and feed CI. Another one factor ANOVA was used to examine the effects of food intake on the biochemical parameter. The values presented were expressed by assigned average standard error of the mean. In the case of significant difference, Tukey HSD test was used to separate homogeneous groups at a significance level of $5 \%$.

\section{Results}

\section{Apparent digestibility and production droppings}

Dietary intakes of DM ranged from 88.43 to $100.97 \mathrm{~g} /$ day (Table-2). DM droppings daily production in rabbits is similar for all diets and ranged from 38.08 to $46.22 \mathrm{~g}$ /day. DM digestibility ranged from $52.39 \%$ to $61.01 \%$ and was similar for the different diets.

\section{Food consumption and weight gain}

Daily consumption of food by diet is presented in Table-3. The total consumption of food in MS

Table-2: Change in digestibility and production droppings in rabbits.

\begin{tabular}{lccc}
\hline Diets & \multicolumn{3}{c}{ Parameters } \\
\cline { 2 - 4 } & $\begin{array}{c}\text { Ingested } \\
\text { (g DM/day) }\end{array}$ & $\begin{array}{c}\text { Droppings } \\
\text { (g DM/day) }\end{array}$ & $\begin{array}{c}\text { CAD } \\
\text { (\% DM) }\end{array}$ \\
\hline R0 & $97.00 \pm 6.12$ & $46.22 \pm 13.22$ & $55.36 \pm 6.84$ \\
R5 & $88.43 \pm 6.12$ & $41.60 \pm 13.22$ & $52.39 \pm 6.84$ \\
R10 & $93.26 \pm 6.12$ & $38.08 \pm 13.22$ & $60.11 \pm 6.84$ \\
R15 & $100.97 \pm 6.12$ & $42.26 \pm 13.22$ & $58.48 \pm 6.84$ \\
R20 & $99.86 \pm 6.12$ & $38.91 \pm 13.22$ & $61.01 \pm 6.84$ \\
p & 0.12 & 0.44 & 0.11 \\
\hline
\end{tabular}

$\mathrm{p}=$ Probability of significance only, DM=Dry matter

$\mathrm{CAD}=$ Coefficient of apparent digestibility during the test ranged from 75.47 to $80.97 \mathrm{~g}$ in rabbits. Body weights of the rabbits at the beginning of the trial was similar ( $p>0.05)$, and no significant differences were noted on the sharp end weight. The vivid average weight gain and the average CI are similar for different rations.

Figure-1 shows the weight change of the animals during the experimental period. It showed that at the beginning of the weights of the test batches are the same $(p>0.05)$. Rabbits showed a linear increase regardless of the diet. At the end of the test, the body weights of the animals ranged from 1897 to $2078 \mathrm{~g}$. No significant difference was observed between the final weights in rabbits receiving different rations of $C$. frutescens ( $\mathrm{p}>0.05$ ). Food CI ranged from $5.95 \pm 1$ to $9.92 \pm 1$ and was similar for the different food rations (Table-3).

\section{Evolution of feed intake, ADG, and feed efficiency}

The evolution of food intake and weight gain of rabbits was presented in Table-4. Food intake, body weight, weight gain, and feed efficiency recorded in rabbits fed with rations with or without $C$. frutescens increased significantly from one period to another during the test $(p<0.05)$. For the same period of feeding, dietary intakes of feed were similar. In the same period, the ADG and CI were similar. The interaction diets period was not significant for the following settings ( $\mathrm{p}>0.05$ ).

\section{Biochemical parameters}

Assessing glycemia in rabbits is shown in Table-5. Blood glucose levels were significantly reduced for diets containing $C$. frutescens. It is lower in rabbits subjected to ration R15 and R20 but higher in rabbits subjected to R0 diet $(\mathrm{p}<0.05)$.

\section{Discussions}

\section{Growth performances}

Ingestion of provender is very low in rabbits. This low consumption could be due to the floury presentation of the food which favored the sorting of the different food particles by animals. The results of Kpodékon et al. [11] showed that granulated feed provides significantly better performance in rabbits than floury ones. Furthermore, the rabbit poorly supports inevitably dust in the flour because it negatively impacts the normal operation of the nasal ways [12]. Similarly, researches of Goby and Rochon [13] on the digestibility and the impact of food sorting showed that rabbits forsake wood chips although rich in fibers.

Table-3: Average consumption and CI.

\begin{tabular}{lcccccc}
\hline Parameters & R0 & R5 & $\mathbf{R 1 0}$ & $\mathbf{R 1 5}$ & $\mathbf{R 2 0}$ & $\mathbf{p}$ \\
\hline Average consumption & $76.22 \pm 7.91^{\mathrm{a}}$ & $75.73 \pm 7.91^{\mathrm{a}}$ & $75.47 \pm 7.91^{\mathrm{a}}$ & $80.97 \pm 7.91^{\mathrm{a}}$ & $77.66 \pm 7.91^{\mathrm{a}}$ & 0.1789 \\
(g/MS) & & & & & \\
Initial body weight $(\mathrm{g})$ & $1276.3 \pm 78.39^{\mathrm{a}}$ & $1224.3 \pm 78.39^{\mathrm{a}}$ & $1231.3 \pm 78.39^{\mathrm{a}}$ & $1265.0 \pm 78.39^{\mathrm{a}}$ & $1261.5 \pm 78.39^{\mathrm{a}}$ & 0.954 \\
Final body weight (g) & $1952.7 \pm 113.59^{\mathrm{a}}$ & $1897.3 \pm 113.59^{\mathrm{a}}$ & $1903.2 \pm 113.59^{\mathrm{a}}$ & $2078.0 \pm 113.59^{\mathrm{a}}$ & $1976.0 \pm 113.59^{\mathrm{a}}$ & 0.519 \\
Daily weight gain (g) & $12.07 \pm 26.89^{\mathrm{a}}$ & $12.01 \pm 26.89^{\mathrm{a}}$ & $11.99 \pm 26.89^{\mathrm{a}}$ & $14.607 \pm 26.89^{\mathrm{a}}$ & $12.75 \pm 26.89^{\mathrm{a}}$ & 0.3243 \\
CI & $6.64 \pm 87.45^{\mathrm{a}}$ & $9.92 \pm 87.45^{\mathrm{a}}$ & $6.83 \pm 87.45^{\mathrm{a}}$ & $5.95 \pm 87.45^{\mathrm{a}}$ & $6.58 \pm 87.45^{\mathrm{a}}$ & 0.5680 \\
\hline
\end{tabular}

$\mathrm{CI}=$ Consumption index, the average in the same line followed by the same letter are not different significantly 


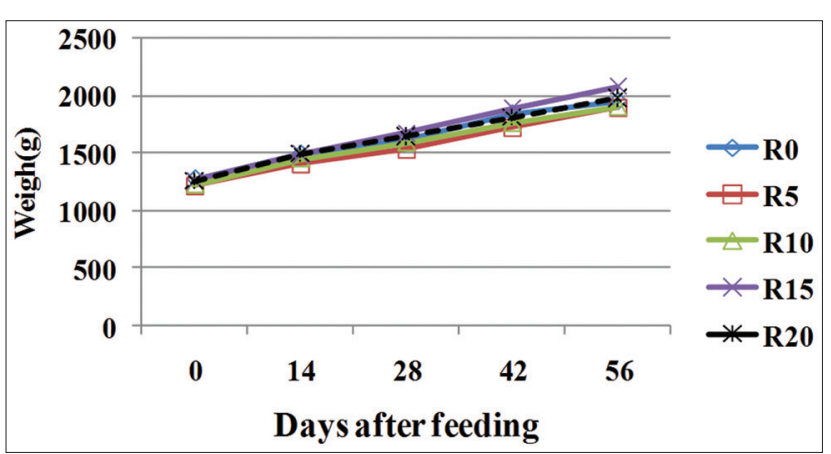

Figure-1: weigh evolution on rabbit

The CAD of the registered DM is similar for the different tested food rations. Digestibility (DM) registered with the different diets is low compared with that (49.8-70.5\%) obtained by Aboh et al. [14] with a ration based on the flour of Mucuna pruriens var. utilis' seeds supplemented with forages in rabbits. However, digestibility of diets used in this study is superior to that obtained $(52.3 \%$ to $57.07 \%)$ by Dougnon et al. [15] in rabbits fed with pellets containing Moringa oleifera leaves. The daily production of droppings is greater than that (8.1-39.1 $\mathrm{g} \mathrm{DM}$ /day) reported by Aboh et al. [14]. As against, it is less than leaves (44.05-53.12 g DM/day). This difference is related to food ingredients and the physiological state of the rabbits because rabbits used had an average live weight of $1615.03 \mathrm{~g}$ against $1056.7 \pm 125.3 \mathrm{~g}$ and $2138.33 \mathrm{~g}$, respectively, for those used by Aboh et al. [14] and Dougnon et al. [15]. The rabbits had a growth rate of 9.17-16.57 g/day during the test which is below the $22 \mathrm{~g}$ /day obtained by Kpodékon et al. [11], who used the same food formula. This difference could also be related to the form of presentation of the food and the physiological condition of rabbits used. Furthermore, Ludy and Mattes [16] suggested that capsaicin, the main constituent of C. frutescens can contribute to weight loss. However, the difference in weight observed in this study could not be attributed to this substance as the witness lot and those containing $C$. frutescens have similar weight gains. Conventionally, feed conversion ratio increases with the age of the animal [11]. The average $\mathrm{CI}$ obtained in this test is similar for all diets. The feed gain ratio (5.2:1) obtained during the last 4 weeks of fattening by Kpodékon et al. [11] with the same floury food is below that recorded during the study. This increase is related not only to the physiological condition of the animals used but also the presentation of the food because according to Kpodékon et al. [11], pelleted feed is consumed; less wasted and has a better feed efficiency than the food floury.

\section{Effect of $\boldsymbol{C}$. frutescens on reducing glycemia through biochemical parameters}

The results obtained reveal that glycemia level decreases with the increase of incorporation rate of $C$. frutescens. Post-prandial glycemia of control that obtained by Dougnon et al. [15] using M. oleifera

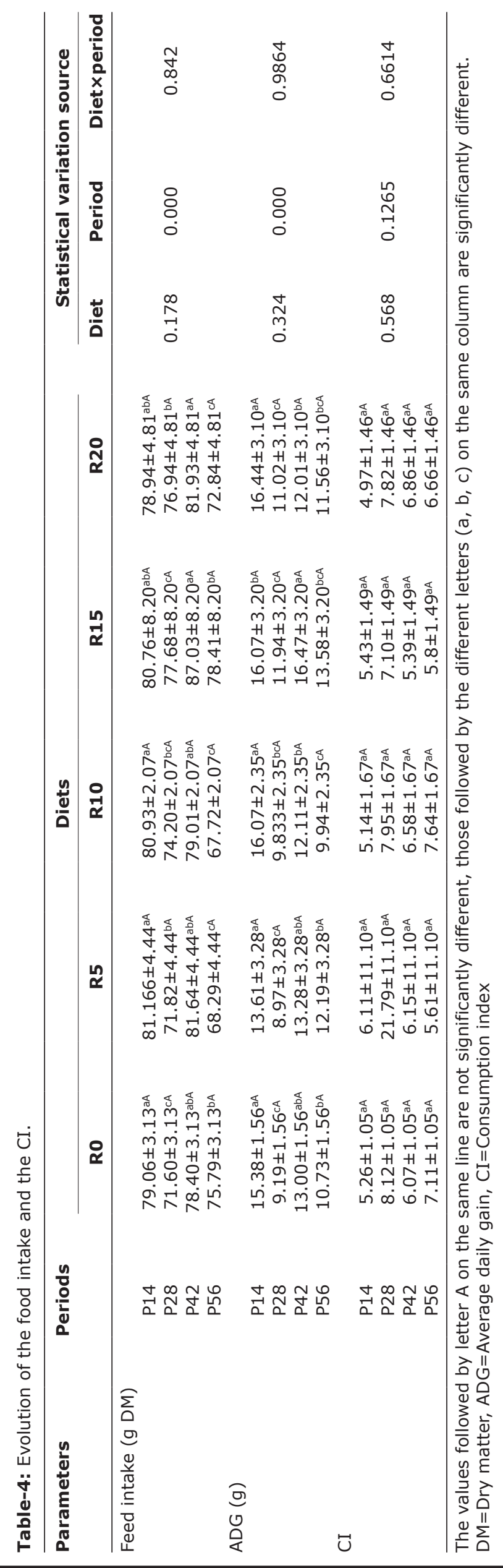

Veterinary World, EISSN: 2231-0916 
Table-5: Glycemia in rabbits.

\begin{tabular}{lc}
\hline Diets & Glycemia $(\mathbf{g} / \mathbf{L})$ \\
\hline R0 & $1.15 \pm 0.02^{\mathrm{a}}$ \\
R5 & $0.98 \pm 0.02^{\mathrm{b}}$ \\
R10 & $0.97 \pm 0.02^{\mathrm{b}}$ \\
R15 & $0.89 \pm 0.02^{\mathrm{c}}$ \\
R20 & $0.86 \pm 0.02^{\mathrm{c}}$ \\
p & 0.0000 \\
\hline
\end{tabular}

Values followed by the different letters $(a, b, c)$ on the same column are significantly different at $5 \%$ threshold.

rabbits is $1.16 \mathrm{~g} / \mathrm{L}$. This result follows those of others studies where rabbits normal glycemia level is around $1 \mathrm{~g} / \mathrm{L}[6,17]$. The analysis of the results shows that, compared to the control lot, the consumption of $C$. frutescens produced variable effects according to the amounts applied for other animals. Indeed, at a low dose $(0.5 \%$ and $1 \%), C$. frutescens has a hypoglycemic activity and reduce glycemia level with a value of $0.98 \mathrm{~g} / \mathrm{L}$ or a reduction of $15.51 \%$. Between $1.5 \%$ and $2 \%$, C. frutescens accentuates the hypoglycemic effect by reducing glycemia to $0.88 \mathrm{~g} / \mathrm{L}$ or a reduction of $24.13 \%$. These results can be explained by the chemical composition of $C$. frutescens, particularly capsaicin (with a rate of $0.1-1.5 \%$ in the plant) whose doses increased in relation to the doses of $C$. frutescens and consequently reduce glycemia level in rabbits. This result is similar to those of Chaiyasit et al. [18] which obtained in humans a reducing of glycemia level with $5 \mathrm{~g}$ of capsaicin, active ingredient of C. frutescens. In a similar way, [19] using fresh C. frutescens fruits in canids, obtain a reduction of glucose level and an increase of the insulin, a hypoglycemic hormone, level.

\section{Conclusion}

From the results of this study, it appears that diets containing $C$. frutescens fruits powder were palatable by rabbits. The powder of $C$. frutescens had no effect on weight gain. However, powder of $C$. frutescens has a hypoglycemic effect which is accentuated when incorporation rate increases in food rations in rabbits.

\section{Authors' Contributions}

The present study was a part of original research work by TJD. He conceptualized the aim of the study, designed, planned, and supervised the experiment. Collection of samples and execution of experimental study were done by him and MG. Analysis of data, interpretation of the results, and drafting of the manuscript were done by TJD. MG helped in analysis, draft and revision of the manuscript. All authors read and approved the manuscript.

\section{Acknowledgments}

The authors are thankful to the Professor and Head, Department of Animals Health and Production, Professor and Head, Laboratory of
Research in Applied Biology for providing their infrastructure and scientific skills in carrying out the research work.

\section{Competing Interests}

The authors declare that they have no competing interests.

\section{References}

1. MAEP (Ministry of Agriculture, Livestock and Fisheries). (2010) Strategic Plan for Agricultural Sector Recovery (PSRSA). Final version. p75.

2. Combes, S. (2004) Nutritional value of rabbit meat. INRA Prod. Anim., 17: 373-383.

3. Darnac, C. (2008) A young faced with the announcement of a diabetes type 1. Memory: Graduate Nurse State. Training Institute in Nursing, Saint Antoine, Paris, p15.

4. Gentilini, M. (1993) Tropical Medicine. Edition Flammarion, Paris. P928.

5. Djrolo, F., Fourn, L. (1999) Prevalence of diabetes mellitus in Benin. Benin Med., 12-13: 70-74.

6. N'Guessan, K., Soro, D., Kouassi, K.E., Amoikon, K.E. and Djaman, A.J. (2008) Effect of the extract of the roots of Jatropha gossypiifolia on blood glucose levels in diabetic rabbits. J. Sci. Pharm. Biol., 9: 13-20.

7. Reichard, P., Nilson, B.Y. and Rosenquist, U. (1993) Power Manual of domestic ruminants in tropical areas. $N$-Engl. $J$. Med, 329: 304

8. Conaway, H., Faas, F., Smith, S. and Sanders, L. (1981) Spontaneous diabetes mellitus in the New Zealand white rabbit. Phys. Charac. Metab., 30: 50-56.

9. Catala, J., Daumas, M., Chanh, AP., Lasserre, B. and Holland, E. (2001) Insulin and glucagon impairments in relation with islet cells morphological changes Following long term pancreatic duct ligation in the rabbit model has of non-insulin-dependent diabetes. Int. J. Exp. Diabetes Res., 2: $101-112$.

10. Islam, M.S. and Choi, H. (2008) Dietary red chilli (Capsicum frutescens $L$.) is insulinotropic Rather than hypoglycemic in Type 2 diabetes model of rats. Phytother. Res. 22(8): 1025-1029.

11. Kpodékon, M., Youssao, AKI., Koutinhouin, GB., Baba, IL., Dessou, JM. and Djago, Y. (2009) Effect of granulation on growth performance, feed efficiency and viability of young rabbits tropical farming conditions. Rev. Elev. Med. Vet. Trop.Country., 62(1): 75-80.

12. Lebas, F., Coudet, P., de Rochambeau, H. and Thébault, R. G. (1996) Rabbits: Breeding and Pathology. Flight. 19. FAO Collection: Animal Production and Health, Rome. p29.

13. Goby, P. and Rochon, J. (1990) Using a farmer feed rabbits for fattening: digestibility and Impact of Food sorting: $5^{\text {th }}$ Days Search rabbit, Paris, France. p12-13.

14. Aboh, A.B., Olaafa, M., Dossou-Gbete, G.S.O., Dossa, A.D. and Djagoun, N. (2002) and voluntary Ingestion apparent digestibility of a ration based flour Mucuna seed var. Used fodder supplemented in rabbits. Tropicultura., 20(4): 165-169.

15. Dougnon, T.J., Aboh, B.A., Kpodékon, T.M., Youssao, A.K.I. and Honvou, S. (2012) Effects of substitution pellets Moringa oleifera leaves on weight performance and biochemical, hematological parameters and parasitic rabbits. $J$. Appl. Pharm. Sci., 2(9): 15-19.

16. Ludy, M.J. and Mattes, R. (2011) Effects of hedonically acceptable red pepper doses on thermogenesis and appetite. Phys. Beha., 102: 251-258.

17. Kadja, B. (1998) Evolution of some diabetic diagnostic parameters in a clinical trial by a phytomedicine(DIACODA). Diploma of Advanced Studies of Biotechnology. CocodyAbidjan University, UFR Biosciences, Laboratory of Biochemical-Pharmacodynamics, p31. 
18. Chaiyasit, K., Khovidhunkit, W. and Wittayalertpanya, S. (2009) Pharmacokinetic and the effect of capsaicin in Capsicum frutescens on decreasing plasma glucose level. $J$. Med. Assoc. Thailand, 92(1): 108-113.
19. Tolan, I., Ragoobirsingh, D. and Morrison, E.Y. (2004) Isolation and purification of the hypoglycemic principle present in Capsicum frutescens. Phytother. Res. 18: 95-96.

\section{$* * * * * * * *$}

